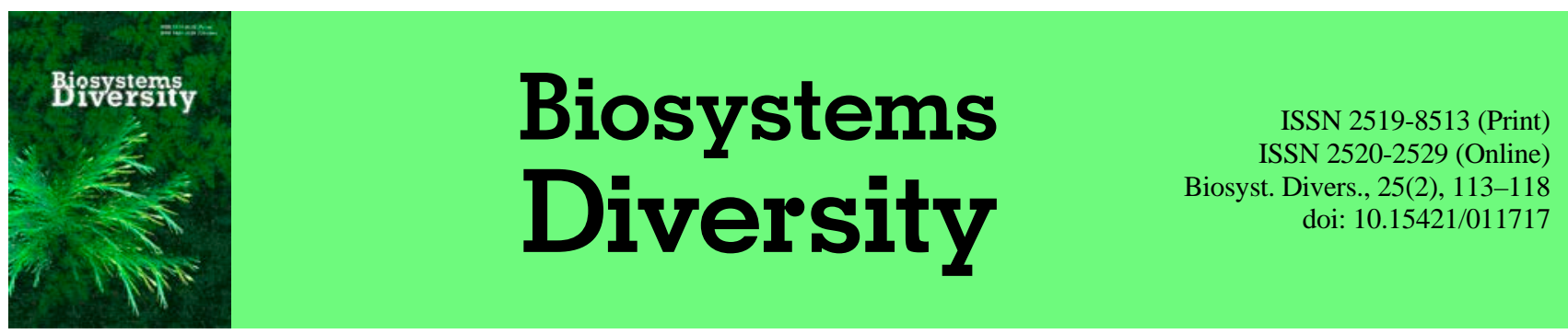

\title{
Biomarkers of metabolism disturbance in bivalve molluscs induced by environmental pollution with processed by-products of oil
}

\author{
E. V. Sukharenko ${ }^{*, * *}$, V. S. Nedzvetsky ${ }^{* * * * *}$, S. V. Kyrychenko ${ }^{* * *}$ \\ *Kerch State Marine Technology Iniversity, Kerch, Ukraine \\ *** Bingol University, Bingol, Turkey \\ **** Oles Honchar Dnipro National University, Dnipro, Ukraine
}

\section{Article info \\ Received 28.04.2017 \\ Received in revised form 16.05.2017 \\ Accepted 17.05.2017}

Kerch State Marine Technology Iniversity, Kerch, Ukraine.

Bingol University, Bingol, Turkey.

Oles Honchar Dnipro National University, Gagarin Ave., 72, Dnipro, 49010, Ukraine.

Tel.: +38-095-338-61-79.

E-mail:

nedzvetskyvictor@gmail.com
Sukharenko, E. V., Nedzvetsky, V. S., \& Kyrychenko, S. V. (2017). Biomarkers of metabolism disturbance in bivalve molluscs induced by environmental pollution with processed by-products of oil. Biosystems Diversity, 25(2), 113-118. doi:10.15421/011717

Processed by-products of oil are the most common pollutants in all river and sea water. The increase in oxidative stress in bivalve molluscs was studied in both tissues of the hepatopancreas and the gill. The model for artificial treatment with processed by-products of oil was performed in a laboratory experiment with the river mollusc Dreissena polymorpha Pallas, 1771. The exposure of the molluscs over 28 days to mazut $50 \mathrm{mg} / \mathrm{l}$ induced significant increase of both final product of lipid peroxidation (LPO) and antioxidant enzime activity. A significant increase in LPO was observed in the hepatopancreas and gill of D. polymorpha treated with mazut compared to the control group. Antioxidant enzyme activity of cartalase, supeoxide dismutase, glutatione reductase and glutatione-S-transferase showed a greater increase (by almost 1.5 times) in the hepatopancreas than in the gill of $D$. polymorpha. A similar LPO growth and modulation of antioxidant enzyme activity were determined in the hepatopancreas and gill of the mussel Mytilus galloprovincialis Lamarck, 1879 collected in an area polluted with resins, hydrocarbons and asphaltenes, Donuzlav lake in the Kerch gulf. Varied cellular reactivation of the antioxidant enzyme system in the hepatopancreas rather than the gill was observed in both kinds of mollusc Dreissena and Mytilus. The obtained results are evidence of the higher sensitivity of the hepatopancreas cells of bivalve molluscs to organic pollutants compared to the gill cells.

Keywords: bivalve mollusks; oil products; oxidative stress; antioxidant enzime activity

\section{Биомаркеры нарушений метаболизма двустворчатых моллюсков в условиях загрязнения среды обитания продуктами переработки нефти}

\author{
Е. В. Сухаренко ${ }^{* * * *}$, В. С. Недзвецкий ${ }^{* * * * *}$, С. В. Кириченко ${ }^{* * *}$ \\ * Керченский государственный морской технологический университет, Керчь, Украина \\ *** Бингольский университет, Бингол, Туриия \\ **** Днепровский начиональный университет имени Олеся Гончара, Днепр, Украина
}

Исследовали влияние продуктов переработки нефти на интенсивность окислительного стресса в гепатопанкреасе и жабрах речной дрейссены (Dreissena polymorpha Pallas, 1771), обитающей в условиях моделирования хронического загрязнения мазутом, и черноморской мидии (Mytilus galloprovincialis Lamarck, 1879), отобранной в бухте Керченской, обитающей в условиях повышенных концентраций углеводородов, смол и асфальтенов. Установлено достоверное повышение уровня конечных продуктов перекисного окисления липидов и рост активности ферментов антиоксидантной защиты в ответ на интоксикацию. Определены отличия показателей окислительного стресса в гепатопанкреасе и жабрах двустворчатых моллюсков. Полученные результаты свидетельствуют о более высокой чувствительности клеток гепатопанкреаса к действию органических поллютантов, по сравнению с жабрами.

Ключевые слова: двустворчатые моллюски; нефтепродукты; окислительный стресс; ферменты антиоксидантной защиты

\section{Введение}

В современных условиях продукты переработки нефти являются наиболее типичными органическими токсикантами, загрязняющими воды Мирового океана. Механизмы токсических эффектов многих промышленных органических ксенобиотиков тесно связаны с изменением окислительно-восстановительного статуса клеток (Fernandez et al., 2010). Нарушение клеточного прооксидант-антиоксидантного баланса и, как следствие, развитие окислительного стресса, является основным индуктором различных патологий от молекулярных окислительных и генотипических повреждений до снижения жизнеспособности и гибели организма. Окислительные повреждения биомолекул, в первую очередь - пероксидное окисление мембранных липидов, оксидация белков, повреждение ДНК, являются наиболее значимыми причинами клеточной и функциональной патологии, и, как следствие, снижения жизнеспособности организмов. Поэтому изучение и выявление молеку- 
лярных маркеров клеточных и функциональных нарушений водных организмов, обитающих в условиях техногенного загрязнения, является одним из приоритетных направлений исследований биологии гидробионтов (Novitsky et al., 2013).

Изменение показателей активности систем антиоксидантной защиты гидробионтов при воздействии техногенных загрязнителей как в природных, так и в модельных экосистемах не вызывает сомнений, однако механизмы регуляции антиоксидантной защиты в условиях действия токсикантов различной природы до сих пор остаются недостаточно раскрытыми. Активность антиоксидантных ферментов, так же как и уровень неферментативной системы антиоксидантов, значительно варьирует в различных типах тканей. Однако общей закономерностью является тот факт, что наиболее высокий потенциал $\mathrm{NAD}(\mathrm{P}) \mathrm{H}-$ зависимой генерации активных форм кислорода наблюдается в тканях животных с наибольшим уровнем потребления кислорода, и в тех органах, где происходит наиболее активная биотрансформация ксенобиотиков (Cappello et al., 2013).

Характерное повышение активности систем антиоксидантной защиты выявлено при воздействии загрязнителей различной химической природы (Ozkan et al., 2017). Следует обратить внимание, что некоторые из обнаруженных эффектов являются временными, вариабельными и зависят от видовой принадлежности. Имеются противоречивые данные в случаях воздействия одного и того же соединения или одновременного действия нескольких поллютантов. В частности, при определении каталазной активности эпителия пищеварительных желез Mytilus galloprovincialis Lamarck, 1879 в лабораторных и природных условиях показано, что в присутствии полициклических ароматических углеводородов (ПАУ) нефти значительно возрастает активность каталазы (Lacroix et al., 2015). В то же время имеются данные, что каталазная активность Mytilus edulis Linnaeus, 1758 повышается при воздействии полихлорированных бифенилов (ПХБ), но не ПАУ (Damiens et al., 2007). Обратный эффект выявлен у двустворчатых моллюсков при воздействии ионов меди и ртути. Orbea et al. (2002) показано, что высокая дозовая нагрузка этих металлов вызывает снижение каталазной активности у двустворчатых моллюсков Adamussium colbecki E. A. Smith, 1902.

Спорным остается вопрос о дозовой зависимости регистрируемых показателей антиоксидантной защиты. Не выявлено корреляции между каталазной активностью и дозовой нагрузкой таких загрязнителей, как ПХБ и ионы металлов у M. edulis (Gomiero et al., 2011). В то же время показана позитивная корреляция между уровнем загрязнения и активностью каталазы в жабрах и пищеварительных железах M. edulis при исследовании популяций моллюсков, обитающих в акваториях Средиземного и Балтийского морей (Fernandez et al., 2010; Turja et al., 2014). Выявлена корреляция между снижением концентрации восстановленного глутатиона и уровнем загрязнения в серии исследований, включающих воздействие ионов меди на M. galloprovincialis (Franco et al., 2016). Показана зависимость активности антиоксидантной защиты от репродуктивного цикла, возраста и сезонности у Mythilus (Jarque et al., 2014). Однако количество информации о патогенетических изменениях водных организмов в условиях промышленного загрязнения окружающей среды ограничено. Подобные исследования осложняются вследствие огромного количества загрязнителей различной химической природы. Дополнительные трудности заключаются в наличии у водных организмов принципиальных отличий (как филогенетических, так и метаболических), что определяет порог их чувствительности к действию различных групп токсикантов.

Двустворчатые моллюски являются удобным объектом для биоиндикации. Эта группа гидробионтов отличается от других доступностью отбора, широкой распространенностью, прикрепленным образом жизни, фильтрационным типом питания. Несмотря на высокий адаптивный потенциал многих видов моллюсков нефтепродукты способны индуцировать систем- ные нарушения, как у отдельных представителей таксонов, так и в биологических популяциях, обитающих в биотопах с повышенной техногенной нагрузкой. Длительное воздействие поллютантов может привести к необратимым патологическим изменениям, снижению репродуктивного потенциала и выживаемости особей. Изучение особенностей возникновения окислительного стресса в тканях двустворчатых моллюсков, обитающих в условиях повышенных концентраций продуктов переработки нефти, позволит получить более объективную оценку нарушений, возникающих в экосистемах под влиянием загрязнителей.

Цель исследования - выявить общие закономерности динамики ответных прооксидантных и антиоксидантных механизмов в гепатопанкреасе и жабрах взрослых половозрелых особей речной дрейссены и черноморской мидии, вызванных присутствием нефтепродуктов, оценить валидность показателей окислительного стресса для оценки опасности промышленных загрязнителей.

\section{Материал и методы исследований}

В экспериментальных моделях использовали взрослых половозрелых особей двустворчатых моллюсков двух видов: D. polymorpha и $M$. galloprovincialis возрастом 4 года, обитающих в природных и воссозданных водоемах. Экспериментальная и контрольная группы речной дрейссены включали по 30 экземпляров гидробионтов, которых содержали в аквариумах объемом 180 литров. Контрольная группа моллюсков обитала в аквариуме с доочищенной речной водой (р. Днепр). В среде обитания экспериментальной группы двустворчатых моллюсков постоянную концентрацию мазута поддерживали на уровне 50 мг/л в течение 28 дней. Замену 1/4 части воды в аквариуме проводили два раза в неделю.

Экспериментальная и контрольная группы черноморской мидии также включали по 30 особей. В качестве экспериментальной группы использовали биотопы, обитающие в бухте Керченская. Контрольная группа состояла из животных, обитающих в условно чистой акватории озера Донузлав.

Биологический материал получали путем гомогенизации гепатопанкреаса и жабер моллюсков при температуре $40{ }^{\circ} \mathrm{C}$ в соотношении $1: 10$ (масса : объем) в 50 мМ трис-буфере $\mathrm{pH}$ 7,8 , который содержал 2 мМ этилендиаминтетраацетат (ЭДТА). Уровень перекисного окисления липидов (ПОЛ) в гомогенатах измеряли с использованием тест-наборов (LPO586, Oxis Int. Inc., USA) методом, который основан на выявлении малонового диальдегида (МДА), образующегося при деградации липидов активными формами кислорода. Содержание малонового диальдегида и 4-гидроксиалкенов определяли по количеству образующихся с тиобарбитуровой кислотой или $\mathrm{N}$-метил-2-фенилиндолом тиобарбитурореактивных веществ (ТБКактивных продуктов) (Ohkawa et al., 1979). Уровень антиоксидантной защиты оценивали по активности каталазы (Abderrahim et al., 2017), супероксиддисмутазы (СОД) (Beyer et al., 1987), глутатионредуктазы (Regoli et al., 2004), глутатион-Sтрансферазы (Gorbi et al., 2004), глутатионпероксидазы (Gunzler et al., 1985). Обработку полученных данных проводили методами математической статистики для малых выборок. Относительное содержание ТБК-активных продуктов и активность ферментов выражали в виде $\mathrm{M} \pm \mathrm{m}$, достоверность различий между группами оценивали при $\mathrm{P}<0,05$ с помощью t-критерия Стьюдента, после проверки гипотез о нормальности распределения.

\section{Результаты}

Определение показателей окислительного стресса в жабpax и гепатопанкреасе двустворчатых моллюсков показало, что количество ТБК-активных продуктов у особей речной дрейссены в условиях хронического загрязнения среды обита- 
ния мазутом было достоверно $(\mathrm{P}<0,05)$ выше, по сравнению с группой двустворчатых моллюсков, содержащихся в подготовленной доочищенной воде (р. Днепр), в среднем на 69\% и 62\% соответственно, что отражает активное протекание процессов биотрансформации в условиях повышенных концентраций органических ксенобиотиков (рис. 1).

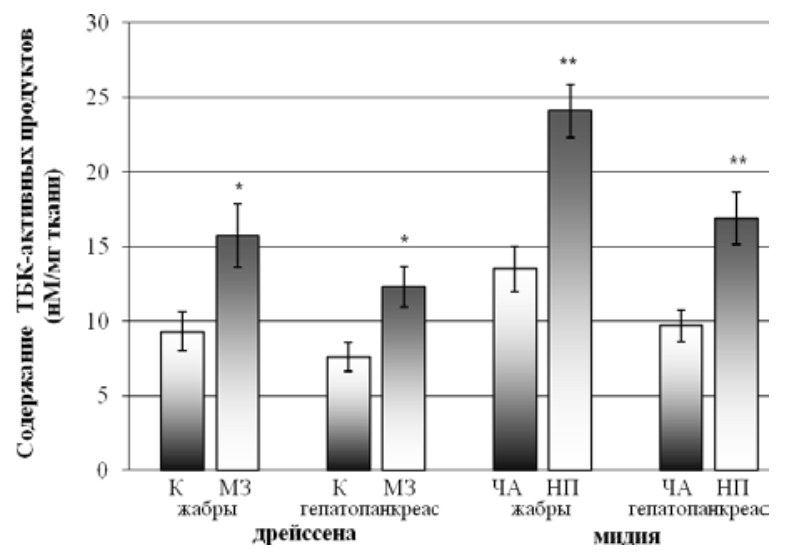

Рис. 1. Содержание конечных продуктов ПОЛ в органах моллюсков при загрязнении среды нефтепродуктами:

$K$ - отсутствие загрязнения, $M 3$ - моделирование загрязнения мазутом, ЧА - условно чистая акватория, $Н П-$ природное загрязнение нефтепродуктами; * - $\mathrm{P}<0,05$, ** - $\mathrm{P}<0,01$ достоверность различий по сравнению с контролем
У взрослых половозрелых особей мидии черноморской уровень перекисного окисления липидов в жабрах и гепатопанкреасе также был достоверно (Р < 0,01) выше, чем у моллюсков этого вида, собранных на условно чистых участках оз. Донузлав. Накопление продуктов деструкции липидов в органах взрослых половозрелых особей черноморской мидии в условиях техногенного загрязнения природной среды было в среднем на 74\% (гепатопанкреас) и 79\% (жабры) выше, чем в органах животных, обитающих в условно чистой акватории. Следует обратить особое внимание на то, что количество конечных продуктов ПОЛ в жабрах как речных, так и морских моллюсков в условиях загрязнения среды нефтепродуктами превышало аналогичные показатели в клетках гепатопанкреаса в среднем в 1,28 (D. polymorpha) и 1,43 раза (M. galloprovincialis).

Сравнительный анализ активности ферментов антиоксидантной системы экспериментальных и контрольных моллюсков (супероксиддисмутазы, каталазы, глутатионредуктазы) показал, что повышение их активности, обеспечивающее снижение уровня активных форм кислорода в тканях двустворчатых моллюсков в условиях загрязнения нефтепродуктами, сопровождается снижением активности глутатион-S-трансферазы, катализирующей утилизацию экзогенных ароматических соединений (табл. 1, 2).

Повышение активности этого фермента в гепатопанкреасе речной дрейссены при моделировании условий хронического загрязнения среды обитания животных мазутом составило в среднем 46\% (Р < 0,01), а в гепатопанкреасе черноморской мидии бухты Керченская - 27\% (P < 0,05) по сравнению с аналогичными показателями особей контрольных групп моллюсков этих же видов.

\section{Таблица 1}

Показатели активности антиоксидантных ферментов в жабрах и гепатопанкреасе половозрелых особей черноморской мидии в природных условиях загрязнения среды обитания нефтепродуктами

\begin{tabular}{|c|c|c|c|c|}
\hline \multirow{2}{*}{ Ферменты, единицы измерения активности } & \multicolumn{2}{|c|}{ Показатели активности в жабрах } & \multicolumn{2}{|c|}{ Показатели активности в гепатопанкреасе } \\
\hline & контрольная группа & экспериментальная группа & контрольная группа & экспериментальная группа \\
\hline Супероксиддисмутаза, ед./мг белка & $7,21 \pm 0,49$ & $10,83 \pm 0,98^{* *}$ & $12,09 \pm 1,03$ & $15,44 \pm 1,25^{*}$ \\
\hline Каталаза, мкмМ/мг белка & $15,66 \pm 1,09$ & $13,20 \pm 0,93$ & $13,35 \pm 1,07$ & $17,83 \pm 1,75^{*}$ \\
\hline Глутатионредуктаза, мкМ/мин· мг белка & $11,32 \pm 1,07$ & $13,03 \pm 1,85$ & $14,47 \pm 1,05$ & $21,34 \pm 1,78^{* *}$ \\
\hline Глутатион-S-трансфераза, нM/мин· мг белка & $135,62 \pm 11,54$ & $120,83 \pm 11,89$ & $59,78 \pm 4,34$ & $34,70 \pm 3,14^{*}$ \\
\hline
\end{tabular}

Примечание: * - $\mathrm{P}<0,05$, **- $\mathrm{P}<0,01$ достоверность различий по сравнению с контролем.

\section{Таблица 2}

Показатели активности антиоксидантных ферментов в жабрах и гепатопанкреасе половозрелых особей речной дрейссены в модельных условиях загрязнения среды обитания мазутом

\begin{tabular}{|c|c|c|c|c|}
\hline \multirow{2}{*}{ Ферменты, единицы измерения активности } & \multicolumn{2}{|c|}{ Показатели активности в жабрах } & \multicolumn{2}{|c|}{ Показатели активности в гепатопанкреасе } \\
\hline & контрольная группа & экспериментальная группа & контрольная группа & экспериментальная группа \\
\hline Супероксиддисмутаза, ед./мг белка & $5,22 \pm 0,47$ & $6,13 \pm 0,49$ & $8,40 \pm 0,55$ & $12,14 \pm 0,95 * *$ \\
\hline Каталаза, мкмМ/мг белка & $21,41 \pm 1,45$ & $19,72 \pm 0,99$ & $18,43 \pm 1,61$ & $25,33 \pm 1,35^{*}$ \\
\hline Глутатионредуктаза, мкМ/мин·мг белка & $12,10 \pm 1,03$ & $16,94 \pm 0,97^{*}$ & $15,79 \pm 1,13$ & $20,27 \pm 1,33^{*}$ \\
\hline Глутатион-S-трансфераза, нМ/мин·мг белка & $104,71 \pm 9,52$ & $93,90 \pm 8,54$ & $52,65 \pm 4,07$ & $32,31 \pm 2,94 *$ \\
\hline
\end{tabular}

Примечание: см. табл. 1.

Результаты определения активности каталазы в органах моллюсков подтверждают более высокий уровень антиоксидантной защиты клеток гепатопанкреаса по сравнению с жабрами. Достоверный $(\mathrm{P}<0,05)$ рост активности этого фермента по сравнению с особями групп двустворчатых моллюсков, принятых в качестве контрольных, составил для D. polymorpha и M. galloprovincialis в среднем $37 \%$ и $34 \%$, соответственно. В то же время отмечается недостоверное снижение активности каталазы в жабрах моллюсков, обитающих в условиях воздействия органических поллютантов. Активность глутатионредуктазы в органах моллюсков в условиях загрязнения продуктами переработки нефти также была ниже в жабрах, чем в гепатопанкреасе.

Напротив, активность глутатион-S-трансферазы в гепатопанкреасе половозрелых особей черноморской мидии, собранных в бухте Керченская была достоверно более низкой, чем у моллюсков, обитающих в акватории оз. Донузлав. Активность глутатион-S-трансферазы в гепатопанкреасе животных экспе- риментальных групп черноморской мидии и речной дрейссены была в среднем на 42\% (P < 0,05) и на 39\% (P < 0,05) ниже, чем у моллюсков, принятых в качестве контроля. Наибольшая активность глутатион-S-трансферазы выявлена в гепатопанкреасе мидий оз. Донузлав, что отражает важную роль этого органа в детоксикации поллютантов у многих животных, в том числе и у моллюсков. Необходимо особо отметить, что в жабрах особей двустворчатых моллюсков в условиях загрязнения среды обитания нефтепродуктами некоторые показатели активности ферментов были не достоверными.

\section{Обсуждение}

Представленные результаты полностью согласуются с данными, полученными в загрязненных промышленными отходами и техногенными катастрофами регионах Средиземного и Балтийского морей (Ruczynska et al., 2011; Ozkan et al., 2017). Повышение активности каталазы и фермента биотрансформа- 
ции ксенобиотиков - цитохрома СYР4Y1 в пищеварительной железе мидий также установлено в условиях антропогенного загрязнения ПАУ (Cappello et al., 2013). Полихлорированные бифенилы (ПХБ-153) ингибируют глутатион-S-трансферазную активность и индуцируют активность глутатионпероксидазы у мидий M. galloprovincialis. В то же время существенных изменений активности ацетилхолинстеразы не выявлено (VidalLinan et al., 2016). Валидность использования биомаркеров окислительного стресса подтверждается результатами биомониторинга водных ресурсов, загрязненных ионами металлов (Franco et al., 2016). Относительно малоизученными биомаркерами являются регуляторы основных метаболических путей. Показаны сходные изменения экспрессии митоген-активированной протеинкиназы (МАРК) при действии различных поллютантов, индуцирующих окислительный стресс в тканях мидий (Chatel et al., 2010).

Несмотря на видовую специфичность, физиологические особенности и условия обитания гидробионтов, в норме антиоксидантной защиты клеток, как правило, достаточно как для локальной детоксикации активных форм кислорода (АФК), так и для предотвращения диффузии этих соединений в клетке. Под действием токсикантов скорость образования АФК может значительно повышаться, изменяя направление метаболических потоков. Нарушения антиоксидантных механизмов сопровождаются характерными процессами, провоцируя окислительный стресс. Однако какие из существующих загрязнителей однозначно вызывают окислительный стресс - один из главных нераскрытых вопросов. Не менее важной, с практической точки зрения, является проблема выявления дозы загрязнителей, при которой они способны индуцировать необратимые повреждения в биосистемах, то есть хронический окислительный стресс, приводящий к развитию патологий, снижению способности к репродукции и жизнеспособности водных организмов. Поскольку только незначительная часть известных загрязнителей обладает непосредственным прооксидантным эффектом, появляются дополнительные направления исследований, связанные с изучением потенциальных активаторов редокс-циклических процессов. Действие таких загрязнителей проявляется в ходе их биотрансформации, например, нитроароматических соединений или ПАУ. Вероятно, только небольшая часть загрязнителей обладает подобными свойствами. Если липофильность различных загрязнителей позволяет им угнетать мембранные функции (в частности, дыхательную цепь митохондрий), то суммарное действие нескольких таких соединений в составе смеси загрязнителей, может проявляться в виде кооперативных эффектов и вести к значительным нарушениям в клетках, тканях и целостном организме. Значение и эффективность показателей окислительного стресса подтверждается также тем, что непосредственные свободно радикальные повреждения в присутствии ПАУ и других продуктов переработки нефти сопровождаются ростом протеолитического расщепления в результате дестабилизации лизосомальных мембран (Turja et al., 2013). Поэтому даже при незначительной прооксидантной активности каждого компонента промышленных загрязнителей их суммарное действие может быть крайне токсичным.

Постоянно возрастающее содержание высокотоксичных загрязнителей в водах всех промышленно развитых стран определяет актуальность поиска биологических маркеров для оценивания потенциального вреда как водным организмам, так и отдаленных последствий для человека. Наиболее опасными для экосистем являются органические ксенобиотики, такие как полихлорированные бифенилы, полихлорированные дибензодиоксины, полихлорированные дибензофураны, полициклические ароматические углеводороды, трибутилин и ионы металлов (Martins et al., 2012). Недавние исследования биоаккумуляции токсикантов, проведенные в заливах Европы, выявили наиболее высокий риск для полициклических ароматических углеводородов (polycyclic aromatic hydrocarbons, PAHs) и полихлорированных бифенилов (polychlorinated biphenyls, PCBs) несмотря на то, что ранее такие соединения были классифицированы как «следовые загрязнители». Чрезвычайно важное значение имеет изучение биологических эффектов PAHs и PCBs, поскольку эти соединения не только индуцируют оксидативный стресс, но и характеризуются высокой генотоксичностью (Martins et al., 2012). Результаты этих исследований показали важность изучения как химических, так и биологических показателей для процедур стандартного мониторинга. В то же время продемонстрирована необходимость мониторинга не только на загрязненных территориях, но и в регионах, граничащих с ними.

В последнее время представлены результаты, подтверждающие перспективность использования ферментов центральных метаболических путей и митохондриальной электон-переносящей цепи для адекватной оценки состояния клеток и степени повреждений. Показана связь между уровнем загрязнения органическими ксенобиотиками и экспрессией цитохрома $\mathrm{P}_{450}$ у рыб (Callionymus lyra Linnaeus, 1758, Limanda limanda (Linnaeus, 1758), Serranus sp., Mullus barbatus Linnaeus, 1758) и моллюсков (D. polymorpha) в условиях действия различных ксенобиотиков, таких как полихлорированные бифенилы и ПАУ (Lopes et al., 2012). Подобные данные подтверждают значимость цитохрома $\mathrm{P}_{450}$ как биомаркера в условиях загрязнения органическими полютантами.

Нарушения, индуцируемые органическими ксенобиотиками, могут вызывать также первичные повреждения митохондрий. В свою очередь, первичные митохондриальные повреждения ведут к снижению уровня АТР в клетках различных клеточных типов. Нарушения работы электрон-переносящей цепи сопровождаются увеличением уровня генерации АФК вследствие «вытекания» электронов. Это способствует развитию оксидативного стресса. Рост генерации АФК индуцирует нарушение окислительно-восстановительного баланса и способствует митохондриальным метаболическим нарушениям в клетках нервной ткани, наиболее чуствительных к действию свободных радикалов. Оксидативный стресс и митохондриальная дисфункция ассоциированы во многих результатах действия повреждающих факторов на всех уровнях организации живых систем. Также большое количество молекулярных механизмов ответственны за митохондриальную дисфункцию вызванную оксидативным стрессом, включая окисление митохондриальных белков, их инактивацию, нарушение транспорта митохондриальных мембран, снижение активности кофакторов и эффективности переноса электронов. Результаты полученные в культуре астроцитов и моделях in vivo дополняют известные данные о роли оксидативного стресса в первичных повреждениях митохондрий и последующем нарушении энергетического метаболизма (Fiskum et al., 2008). Генерация оксидативного стресса и нарушения цитоскелета астроцитов показаны в мозге солнечного окуня как результат хронического действия ионов алюминия, который является одним из самых распространенных токсикантов (Novitsky et al., 2013).

Перспективным является проведение комплексных исследований биологических эффектов поллютантов ионов металлов и РАНs, способных аккумулироваться в тканях гидробионтов, особенно моллюсков. Набор биомаркеров, который отражает воздействие загрязнителей таких классов, должен включать показатели оксидативного стресса, повреждения лизосомальных и плазматических мембран, пролиферации пероксисом, генотоксические эффекты и повреждения ДНК (Bocchetti et al., 2008). В Европейских странах одним из эффективных способов борьбы с промышленным загрязнением окружающей среды признается удаление и очистка седиментационных слоев (донных отложений).

Несмотря на отказ от этилированного бензина во всех развитых странах, количество свинца в донных отложениях промышленно развитых регионов остается критически высоким (Bocchetti et al., 2008). 
Использование двустворчатых моллюсков для оценки степени антропогенного загрязнения в реках Италии показало, что биоаккумуляция ксенобиотиков и ответ биомаркеров оксидативного стресса, генотоксичности и лизосомального ответа не имеет прямой зависимости (Guidi et al., 2010). В первую очередь, это связано с различной степенью биоаккумуляции для разных по природе ксенобиотиков, которая, в свою очередь, определяется интенсивностью биотрансформации в организмах гидробионтов и экскреции в среду. Неоднозначность ответа биомаркеров оксидативного стресса на различные концентрации загрязнителей также определяется индивидуальными возможностями антиоксидантных ферментативных систем к нейтрализации свободных радикалов в условиях действия токсичных ксенобиотиков. Несмотря на подобные трудности в интерпретации результатов, даже средний уровень загрязнения выявил изменения оксидативных биомаркеров, также, как и развитие хромосомных и клеточных повреждений у мидий подверженных действию комплекса антропогенных загрязнителей.

Сравнительный анализ показателей окислительного стресса и активности ферментов антиоксидантной защиты у морских и речных двустворчатых моллюсков M. galloprovincialis и D. polymorpha указывает на значительные нарушения метаболизма в присутствии повышенных концентраций продуктов переработки нефти. Представленные данные дают основания заключить, что наиболее существенные изменения у моллюсков при действии органических загрязнителей наблюдаются в клетках гепатопанкреаса, где показатели окислительного стресса и активности антиоксидантной ферментной системы организма обладают наиболее высокой чувствительностью (Cappello et al., 2013).

\section{Выводы}

Полученные результаты свидетельствуют о причинноследственной связи между токсическими эффектами нефтепродуктов и генерацией клеточного ответа у морских и речных моллюсков. Показатели активности ферментов антиоксидантного комплекса (супероксиддисмутазы, каталазы, глутатионредуктазы, глутатион-S-трансферазы) и уровень конечных продуктов ПОЛ в тканях особей половозрелых двустворчатых моллюсков указывают на то, что в условиях загрязнения среды обитания продуктами переработки нефти проокислительные процессы, характерные для состояния окислительного стресса, резко стимулированы. Эти молекулярные маркеры демонстрируют перспективность и высокую эффективность для биоиндикации и биомониторинга функционального состояния моллюсков при загрязнении морских и пресноводных экосистем.

\section{References}

Abderrahim, M., Arribas, S. M., \& Condezo-Hoyos, L. (2017). A novel pyrogallol red-based assay to assess catalase activity: Optimization by response surface methodology. Talanta, 166(1), 349-356.

Beyer, W. F., Jr, \& Fridovich, I. (1987). Assaying for superoxide dismutase activity: Some large consequences of minor changes in conditions. Analytical Biochemistry, 161, 559-566.

Bocchetti, R., Fattorini, D., Pisanelli, B., Macchia, S., Oliviero, L., Pilato, F., Pellegrini, D., \& Regoli, F. (2008). Contaminant accumulation and biomarker responses in caged mussels, Mytilus galloprovincialis, to evaluate bioavailability and toxicological effects of remobilized chemicals during dredging and disposal operations in harbour areas. Aquatic Toxicology, 89(4), 257-266.

Cappello, T., Maisano, M., D'Agata, A., Natalotto, A., Mauceri, A., Fasulo, S. (2013). Effects of environmental pollution in caged mussels (Mytilus galloprovincialis). Marine Environmental Researchs, 91, 52-60.

Chatel, A., Hamer, B., Talarmin, H., Dorange, G., Schroder, H. C., Muller, W. E. (2010). Activation of MAP kinase signaling pathway in the mussel Mytilus galloprovincialis as biomarker of environmental pollution. Aquatic Toxicology, 96(4), 247-255.

Damiens, G., Gnassia-Barelli, M., Loques, F., Romeo, M., \& Salbert, V. (2007). Integrated biomarker response index as a useful tool for environmental assessment evaluated using transplanted mussels. Chemosphere, 66(3), 574-583.

Fernandez, B., Campillo, J. A., Martinez-Gomez, C., \& Benedicto, J. (2010). Antioxidant responses in gills of mussel (Mytilus galloprovincialis) as biomarkers of environmental stress along the Spanish Mediterranean coast. Aquatic Toxicology, 99(2), 186-197.

Fiskum, G., Danilov, C. A., Mehrabian, Z., Bambrick, L. L., Kristian, T., McKenna, M. C., Hopkins, I., Richards, E. M., \& Rosenthal, R. E. (2008). Postischemic oxidative stress promotes mitochondrial metabolic failure in neurons and astrocytes. Annals of the New York Academy of Sciences, 1147, 129-138.

Franco, L., Romero, D., Garcia-Navarro, J. A., Teles, M., \& Tvarijonaviciute, A (2016). Esterase activity (EA), total oxidant status (TOS) and total antioxidant capacity (TAC) in gills of Mytilus galloprovincialis exposed to pollutants: Analytical validation and effects evaluation by single and mixed heavy metal exposure. Marine Pollution Bulletin, 102(1), 30-35.

Gomiero, A., Da Ros, L., Nasci, C., Meneghetti, F., Spagnolo, A., \& Fabi, G. (2011). Integrated use of biomarkers in the mussel Mytilus galloprovincialis for assessing off-shore gas platforms in the Adriatic Sea: Results of a twoyear biomonitoring program. Marine Pollution Bulletin, 62(11), 2483-2495.

Gorbi, S., Pellegrini, D., Tedesco, S., \& Regoli, F. (2004). Antioxidant efficiency and detoxification enzymes in spotted dogfish Scyliorhinus canicula. Marine Environmental Research, 58(2-5), 293-297.

Guidi, P., Frenzilli, G., Benedetti, M., Bernardeschi, M., Falleni, A., Fattorini, D. Regoli, F., Scarcelli, V., \& Nigro, M. (2010). Antioxidant, genotoxic and lysosomal biomarkers in the freshwater bivalve (Unio pictorum) transplanted in a metal polluted river basin. Aquatic Toxicology, 100(1), 75-83.

Gunzler, W. A., Flohe, L., \& Greenwald, E. R. (1985). Glutathione Peroxidase. In: CRC handbook of methods for oxygen radical research. CRC Press, Boston.

Jarque, S., Prats, E., Olivares, A., Casado, M., Ramon, M., \& Pina, B. (2014). Seasonal variations of gene expression biomarkers in Mytilus galloprovincialis cultured populations: Temperature, oxidative stress and reproductive cycle as major modulators. Science of the Total Environment, 499, 363-372.

Lacroix, C., Richard, G., Seguineau, C., Guyomarch, J., Moraga, D., \& Auffret, M. (2015). Active and passive biomonitoring suggest metabolic adaptation in blue mussels (Mytilus spp.) chronically exposed to a moderate contamination in Brest harbor (France). Aquatic Toxicology, 162, 37-126.

Lopes, B., Ferreira, A. M., \& Bebianno, M. J. (2012). Responses of CYP450 dependent system to aliphatic and aromatic hydrocarbons body burden in transplanted mussels from South coast of Portugal. Ecotoxicology, 21, 730-749.

Martins, M., Costa, P. M., Raimundo, J., Vale, C., Ferreira, A. M., \& Costa, M. H. (2012). Impact of remobilized contaminants in Mytilus edulis during dredging operations in a harbour area: Bioaccumulation and biomarker responses. Ecotoxicology and Environmental Safety, 85, 96-103.

Novitsky, R. A., Sukharenko, E. V., Nedzvetsky, V. S. (2013). Molecular biomarkers of $\mathrm{Al}^{3+}$ ions effect on oxidative stress generation and cell reactivity in fish Lepomis gibbosus (Pisces: Centrarchidae). Hydrobiological Journal, 49(6), 65-75.

Ohkawa, H., Ohishi, N., \& Yagi, K. (1979). Assay for lipid peroxides in animal tissues by thiobarbituric acid reaction. Analytical Biochemistry, 95(2), 351-358.

Orbea, A., Ortiz-Zarragoitia, M., Sole, M., Porte, C., \& Cajaraville, M. P. (2002). Antioxidant enzymes and peroxisome proliferation in relation to contaminant body burdens of PAHs and PCBs in bivalve molluscs, crabs and fish from the Urdaibai and Plentzia estuaries (Bay of Biscay). Aquat Toxicology, 58, 75-98.

Ozkan, D., Dagdeviren, M., Katalay, S., Guner, A., \& Yavaşoglu, N. U. (2017). Multi-biomarker responses after exposure to pollution in the mediterranean mussels (Mytilus galloprovincialis L.) in the Aegean Coast of Turkey. Bulletin of Environmental Contamination and Toxicology, 98(1), 46-52.

Regoli, F., Nigro, M., Chierici, E., Cerrano, C., Schiapparelli, S., Totti, C., \& Bavestrello, G. (2004). Variations of antioxidant efficiency and presence of endosymbiotic diatoms in the Antarctic porifera Haliclona dancoi. Marine Environmental Research, 58(2-5), 637-640.

Ruczynska, W. M., Szlinder-Richert, J., Malesa-Ciecwierz, M., \& Warzocha, J. (2011). Assessment of PAH pollution in the southern Baltic Sea through the analysis of sediment, mussels and fish bile. Journal of Environmental Monitoring, 13(9), 2535-2542.

Sukharenko, E. V., Nedzvetsky, V. S., \& Maximov, V. I. (2015) The characteristic of molecular processes of a biotrasformation in a gepatopankreas and gills of adults the polovozrelykh of individuals of a river dreyssena (Dreyssena polymorpha) in the conditions of pollution of the habitat. Veterinarian, 6, 27-32.

Turja, R., Hoher, N., Snoeijs, P., Barsienė, J., Butrimavicienė, L., Kuznetsova, T., Kholodkevich, S. V., Devier, M. H., Budzinski, H., \& Lehtonen, K. K. (2014). A multibiomarker approach to the assessment of pollution impacts in 
two Baltic Sea coastal areas in Sweden using caged mussels (Mytilus trossulus). Science of The Total Environment, 473-474, 398-409.

Turja, R., Soirinsuo, A., Budzinski, H., Devier, M. H., \& Lehtonen, K. K. (2013). Biomarker responses and accumulation of hazardous substances in mussels (Mytilus trossulus) transplanted along a pollution gradient close to an oil terminal in the Gulf of Finland (Baltic Sea). Comparative
Biochemistry and Physiology Part C: Toxicology and Pharmacology, 157(1), 80-92.

Vidal-Linan, L., Bellas, J., Soriano, J. A., Concha-Grana, E., Muniategui, S., \& Beiras, R. (2016). Bioaccumulation of PCB-153 and effects on molecular biomarkers acetylcholinesterase, glutathione-S-transferase and glutathione peroxidase in Mytilus galloprovincialis mussels. Environmental Pollution, 214, 885-891. 